\title{
Social and Industrial Development of Rural Communities
}

$\mathrm{T}$ HE twenty-third report of the Development Commissioners* for the year ended March 31, 1933 , is much more than a mere collection of official statements of the various activities directed by the Commission. The report no longer sets forth the work in progress at research institutes and advisory centres in Great Britain, as this will be dealt with in the publications of the Agricultural Research Council and the departments of agriculture. Brief accounts of the institutes are given, touching on their raison d'être, personnel and finances, but the chief emphasis is laid on the progress of various schemes which the general public scarcely realises as coming within the scope of the work of the Commission.

In most rural districts in Great Britain, very slow progress has been made by electrical supply schemes, as the cost has been beyond the reach of most rural dwellers, largely because of the distance that current has to be conducted as compared with urban areas. Special arrangements were made to supply a rural area in Bedfordshire with electricity under special terms, and considerable progress has been made during the three years of the scheme. The majority of rural customers use electricity for domestic purposes only, but its use in farm buildings and dairies is gradually spreading, and about 62 per cent of all the premises within the area are now receiving supplies. The most important factor responsible for the progress made seems to be the adoption of a lower tariff than in most rural areas, together with special facilities offered by the Bedfordshire Corpora. tion for assisted wiring without consumption guarantee. It is anticipated that by the end of 1934 revenue from this source will exceed expenditure and yield surpluses from which the advance from the Development Fund will be repaid.

For the last twelve years, the Rural Industries Bureau has been working largely for the benefit of local craftsmen, in association with the National Council of Social Service, the Rural Community Councils and Women's Institutes. Progress was at first slow, partly because of the difficulty of establishing contact with isolated village craftsmen, and partly because such craftsmen viewed the activities of the Bureau with suspicion and failed to realise that it had any value in putting them into touch with the work they needed so badly. Now that confidence has been established, about two thousand craftsmen are in touch with the Bureau's officers,

- Development Commission. Twenty-third Report of the Develop ment Commissioners, being for the Year ended 31st March, 1933.
Pp. 107. (London: H.M. Stationery Office, 1933.) 28. net. but it is probable that at least three times as many have not yet been reached. The activities of the Bureau are multifarious; craftsmen are trained to make such things as fine ironwork, good furniture and substantial fruit baskets ; local textile industries are reviewed and their products adapted to presentday requirements; exhibitions are staged at county shows and local fairs, and every endeavour is made to bring the craftsman into touch with a market for his productions. In general, both the purpose and policy of the Bureau may be summed up in the words, the "Craftsman's Friend".

For some years the Society of Friends has given special attention to allotment cultivation as a means of alleviating distress. In 1930, Government granted $£ 80,000$ to the Ministry of Agriculture towards aiding the provision of allotments for the unemployed, but after the financial erisis in 1931 this grant was not continued. However, the Society of Friends decided to carry on the work itself and to obtain money by public subscription. Its efforts were so successful that the 1933 programme catered for providing 100,000 persons with allotments, and Government assistance was applied for. The application was referred to the Development Commissioners, who recommended a grant of $£ 10,000$ on the $£ 1$ for $£ 1$ basis, and a further sum not exceeding $£ 2,500$ on the basis of $£ 1$ for each $£ 2$ raised by the Society of Friends. Certain conditions were laid down as to the application of the grant, which included Scotland in its scope. In actual practice, the cost of carrying out the scheme for the cropping year 1933 worked out substantially below the estimate, chiefly owing to the low price of seed potatoes.

On the fisheries and harbours side, much progress has been made in the extension and improvement of the breeding of shellfish. A simple and effective method has been evolved of rendering mussels and oysters contaminated by sewage clean and safe for human consumption, by placing them in tanks of sea-water made sterile by the addition of minute quantities of chlorine, which is afterwards removed so as to allow the shellfish to function freely. The investigations on the furunculosis disease of salmon, sea trout and fresh-water fish have advanced considerably, but show that there are formidable difficulties in preventing the spread of the disease.

The diverse instances touched on above indicate the wide range of social problems dealt with by the Development Commissioners and demonstrate very clearly the value of their activities in connexion with many and varied aspects of national life.

\section{Recent Researches on Fuel Technology}

AYONE casting his mind back for twenty - years cannot fail to remark on the greatly increased interest in the problems of manufacture and utilisation of fuels. This is largely, although not entirely, a legacy of the War and its interruption of normal supplies, the rise of economic nationalism and the lesson of what could be achieved by the purposeful application of science. Early efforts were individual, in private concerns or educational institutions, but all over the world, State action has followed; for example, the British Fuel
Research Board was established to study the production of liquid fuel for the Navy by the carbonisation of coal at low temperatures. Experience soon showed that no immediate solution lay in that direction, and the Report of the Board for the year ending March 31, 1933 (H.M. Stationery Office, $2 s$. $6 d$. net) shows that this aim is still unattained, although retorts of new design are giving promising service.

A limited quantity of oil and spirit from lowtemperature tar has been supplied commercially to 